\title{
Tradition, Innovation, Re-enactment: Hans Talhoffer's Unusual Weapons
}

\author{
Ariella Elema \\ ariella.elema@yahoo.com
}

Multiple manuscripts of Hans Talhoffer's fifteenth-century Fechtbuch depict duels between combatants wielding faceted clubs and tall shields, as well as combatants in tight-fitting grey clothing, and duels between a man and a woman. Legal ordinances and court records from Talhoffer's time and before him provide context for these scenarios and this equipment. Customary law regarding judicial duels varied significantly between German regions. It also changed over time, shaped by influences that sometimes originated well outside German-speaking lands. Talhoffer's work and the Fechtbücher that followed him reflect a practice that spanned multiple regions, preserving fading traditions while embracing new innovations.

Keywords - trials by battle, trials by combat, judicial duels, Hans Talhoffer, clubs (weapons), swords, shields

\section{TALHOFFER'S EQUIPMENT}

The fifteenth-century manuscripts attributed to Hans Talhoffer contain some of the most easily recognizable and most reproduced images in the European fight book corpus. In particular, Talhoffer's sequences of drawings depicting judicial duellists on foot battling with tall shields, and a woman fighting a man, spark curiosity both inside the historical European martial arts community and outside it: the unusual clubs, the fancifully shaped shields taller than their users, and the tight body suits seem utterly unlike most other images of combat produced in his period or before it. ${ }^{1}$ Where did such equipment come from? Was it ever employed in a recorded judicial duel? Are there examples to be found beyond Talhoffer and the lineage of German Fechtbücher that followed his example?

\footnotetext{
1 The manuscripts of Talhoffer containing the sequences with long shields are the following: Gotha, Universitäts- und Forschungsbibliothek, MS Chart.A.558, ff. 24v-48r; Copenhagen, Kongelike Bibliotek, MS Thott 290.2, ff. 97v-110r; Berlin, Stiftung Preußischer Kulturbesitz MS 78.A.15; ff. 37v and $62 \mathrm{r}-77 \mathrm{v}$; and Munich, Bayerische Staatsbibliothek, Cod. icon. 394a, ff. 53v-86r. The only one of these manuscripts containing a duel between a man and a woman is MS Thott 290.2, ff. 80r-84r. A fifth manuscript, belonging to the private collection of the Königsegg-Aulendorff family, does not contain these sequences, and two later copies, in the Kunsthistorisches Museum in Vienna and the Universitätsbibliothek Augsburg respectively, are also without them. Digitizations of all the manuscripts can presently be viewed at the website Wiktenauer at: https://wiktenauer.com/wiki/Hans Talhoffer.
} 


\section{I.1. Historiography}

The literature on the history of trial procedure in German-speaking lands has remarkably little to say about duellists' weapons and equipment in trials by battle. While Jacob Grimm briefly discussed the existence of judicial duels as a means of legal proof, he was primarily interested in the way that they contributed to the development of rules of evidence, and not in their literal enactment. Friedrich Unger, the first to write an entire book about German trials by battle, was preoccupied with their supposed Germanic origins. Although he referred in passing to weapons several times, he did not seem to think their form needed to be elaborated upon. Of the nineteenth-century historians, only Joseph Würdinger and Henry Charles Lea contemplated the subject, finding a handful of references in medieval German legal codes. ${ }^{2}$

In the early twentieth century, Hans Fehr knew that judicial duels had sometimes been fought with weapons other than swords but elided this fact, first discussing humankind's progression from wrestling, to fist fighting, to the use of maces, then insisting that his book was not about those things. Only in his endnotes does he observe that some medieval German regions did, indeed, hold judicial duels with clubs. (We may perhaps suspect Fehr, a junior professor and former corps student when he wrote the book in 1908 , of wanting to protect duelling culture's aristocratic image at a time when lethal duels were still very much alive in the German academy but increasingly condemned outside it.) Hermann Nottarp stands virtually alone among the legal historians for discussing weapons at any length. However, concerning the origins of tall shields and faceted clubs, the evidence provided by all of these scholars circles back to the manuscripts of Talhoffer and the Fechtbuch lineage that followed him. ${ }^{3}$

More recent books, such as those of Bartlett and Neumann, concern themselves with the mentalités that powered the judicial process. This focus is partly a consequence of the surviving sources. Courts of law in German speaking lands adopted written recordkeeping centuries later than their English and French counterparts. There are very few charters or case records from which to draw details of individual duels, and information must be gleaned mainly from law books and chronicles. In addition, judicial duelling was always an unusual way to resolve a lawsuit. As Stephen White has noted, medieval litigants in trials by battle usually managed to broker a settlement outside of court before they arrived at the combat stage of the process. ${ }^{4}$

On the other side of the coin, martial arts research is very much aware of the German Fechtbücher but, with the exception of Fortner, gives almost no notice to the great volume

2 Grimm, Deutsche Rechtsaltertbümer, 2nd ed., 929. Unger, Der gerichtliche Zweikampf, 11, 22, 55. Würdinger, Beiträge, 13, citing Paulus Kal's Fechtbuch. Lea, Duel and the Oath, 154, citing Würdinger and reproducing an image from the duel between a man and a woman.

${ }^{3}$ Fehr, Der Zweikampf, 4; 41, n. 7; 46, n. 37. Nottarp, Gottesurteilstudien, 283-7.

${ }_{4}^{4}$ Bartlett, Trial by Fire and Water, 103-126. Neumann, Der gerichtliche Zweikampf. Two neglected collections of case law for late medieval German trials by battle can be found in Jung's Miscellaneorum, pp. 182-213, and Zwierlein's Abhandlung, no. 16, pp. 31-6. On brokering settlements: Stephen D. White, "Proposing the Ordeal and Avoiding It," 89-123. 
of legal sources that preceded them, struggling to find examples of clubs or maces, shields, and clothing analogous to the ones Talhoffer illustrated. A few scholars of archaeology see similarities between surviving weapons and the Talhoffer images. Fărcaș notes the resemblance between the "prismatic" bronze mace heads found in Transylvania and the faceted wooden clubs of the German Fechtbücher, but he does not suggest that the design was transmitted from one place to the other. Talaga sees a relationship between the faceted pommel of an estoc in Wawel Castle in Kraków, the spiked pommels of the weapons depicted in the Thott manuscript, and the treatise of Filippo Vadi. He concludes on this basis that the estoc was a judicial combat weapon, without providing evidence for judicial duelling with edged weapons in Poland in the late fourteenth or early fifteenth centuries, the period to which the sword is dated. ${ }^{5}$

The missing piece in all these works is an overview of the evidence for specialized judicial duelling equipment and practice in the medieval German realm that Talhoffer knew. This article attempts to fill that gap.

\section{I.2. Clubs and Maces}

In most of Europe, for most of the history of trial by battle, the usual weapon of judicial combat was not a sword but rather a wooden club. It had not always been thus: the socalled barbarian laws of the early Middle Ages do indeed mention duels with swords, but these would later fall out of fashion. The laws of the Ripuarian Franks, originating around Cologne circa 630 CE, speak of judicial combat "cum gladio" in disputes about whether a freedman had really been freed, while the laws of the Alemanni farther south, compiled around 730 , also record a specific legal procedure by means of "spata tracta". Moving west, the early ninth century bishop Agobard of Lyons railed against the laws of the Burgundians, which allowed duels with spears and swords (telis et gladiis). ${ }^{6}$

At the beginning of the ninth century, a change seems to have occurred throughout the Carolingian Empire, which at the time encompassed most of the land that makes up modern France, Germany and northern Italy. The emperor Charlemagne issued a capitulary in 803 creating an addendum to the laws of the Ripuarian Franks and providing several alternatives for settling a lawsuit about whether one man had wounded another. One of the options was to hold a judicial duel, but this time the combat was to be fought not with swords but with a shield and club (scuto et fuste). In 818 or 819, around the same time that Agobard was writing his treatise, Charlemagne's heir Louis the Pious extended the procedure to cases of theft, in a capitulary that spread more widely across the empire. ${ }^{7}$

5 Fortner, “'Kempflich angesprochen:' über Kampfgerichte und Kampfrecht,” pp. 10-22. Fărcaș, "Maces in Medieval Transylvania," 76-84. Talaga, "A Kampfschwert from the $15^{\text {th }}$ Century," 8.

${ }^{6}$ Lex Ribvaria, ed. Beyerle \& Buchner, $\int 60.2$, p. 108. Lex Alamannorum, ed. Lehman \& Eckhardt, 2nd ed., \ LIV.2 (LVI.1), p. 118. Agobard, Adversus legem Gundobadi in Agobardi Lvgdvnensis: Opera omnia, ed. L. Van Acker, c. XIII, p. 27.

7 Capitularia regum Francorum, ed. Boretius, no. 41, §4, p. 117; no. 136, §2, p. 281. 
From that point forward, clubs became the normal weapons of judicial combat in most of the Frankish world and swords became the exception.

German laws of the high and late Middle Ages need to be seen in the context of this widespread use of wooden clubs for judicial duelling. In the French-speaking lands that had once been the western half of the empire, legal customals and the lawsuits recorded in charters speak of duels with clubs in all instances except criminal cases where the accused was a nobleman. In all other criminal cases the prescribed weapon was a wooden club, and in all suits concerning the possession of land the battle, if there was one, was fought by champions with clubs. "Champions should not fight each other with clubs that exceed three feet in length to the base of the hand," wrote King Philip Augustus in 1215, "or they can fight with a shorter length, if they want." When such weapons are depicted in high medieval illustrations, they resemble short baseball bats. In England and some jurisdictions on the Continent, duelling clubs had "horned" or T-shaped heads, ranging in shape from modest knobs to spikes resembling pickaxes. This latter type were referred to in Latin as baculi cornuti or in French as bastons cornus. ${ }^{8}$

French legal practice with regard to duelling weapons influenced England, where trial by battle was introduced by the Normans after 1066, but also the French-speaking parts of Flanders and sections of northern Iberia. The Fuero general of Navarre from 1238 stipulates that suspected thieves should fight judicial duels "á escudo et á baston".

Moreover, the customary use of clubs extended even farther afield. Capitularies of Charlemagne and his grandson Lothair were recorded in the eleventh-century Liber Papiensis compiled in Pavia, and thereby became the basis of the Lombard law that formed a foundation of precedents for the patchwork of regional secular law throughout northern Italy. "Where it is clearly apparent that he who initiated an accusation or he who is defending wishes to perjure himself, it is better that they go into the field and fight fairly with clubs than that they commit perjury," said the book, quoting Charlemagne. "If two witnesses testify concerning some matter and disagree," said another section, based on the judgements of Louis the Pious, "then let the count elect one person from one party and one from the other, and let those two fight with shields and clubs." The customary law of Milan, recorded in 1215, said "Know that [a judicial duel] is always fought by means of champions with a shield on their head and a club (fuste), unless it is carried out otherwise by the consent of the parties." Around 1318, a Paduan writer thought club battles were used in even more kinds of cases: "The custom of the ancients was this: if two nobles or powerful men had engaged in a suit of homicide among themselves, each party was to find himself a hired champion, and on the ordained day these two champions ... [were] armed with shields, clubs and maces of wood (clypeis, baculis et maschariis de ligno)." Even

\footnotetext{
8 Judicial duels were, in fact, exceedingly rare in lawsuits of all kinds. See Elema, "Trial by Battle in France and England," 90-96, 134-9. Philip Augustus: Laurière, Ordonnances des roys de France de la troisième race, vol. 1, p. 35. For an example of bat-like clubs, see a late copy of the Coutumier de Normandie, Pierpont Morgan MS M.457, f. 85v. Baculi cornuti: Russell, "Accoutrements of Battle," 232-6; Elema, 249-50; Canel, "Le Combat judiciare en Normandie,” 585-6.
}

${ }^{9}$ Fuero general de Navarra, ed. Ilarregui \& Lapuerta, lib. V, tit. VII.1-3, p. 110.

6 Acta Periodica Duellatorum 7(1), 2019, Scholarly section 
Holy Roman Emperor Frederick II's legal code for Sicily, the Constitutions of Melfi, said "Champions should have equal cudgels, neither spiny, nor spiked, nor having horns." In all of these Italian legal texts, swords were never mentioned as weapons for judicial combat. Sword duels would, however, arise later in the fourteenth century in the context of military tribunals, which had not developed as much formal evidential procedure. ${ }^{10}$

It is in this context that the most influential legal treatise of the Holy Roman Empire, the thirteenth-century Sachsenspiegel, is unusual in that it prescribes the use of swords for all participants in judicial duels. Written sometime between 1225 and 1235, this text recorded the customary law of Saxony, a region then comprising much of what is now northern Germany. In criminal cases involving violence, an accuser could demand a duel from a man of equal standing or lesser status, and the judge was to supply a sword and shield to the accused if he needed it. According to the text, each combatant should have "a naked sword in hand, and one or two girded at his waist, as he prefers." He could switch from one weapon to the other during the combat. This book was highly influential on other German legal treatises of the thirteenth century. The Deutschenspiegel, and the Schwabenspiegel, compiled respectively in Regensburg circa 1270 and in Augsburg around 1275 , copied it nearly word for word in their own discussions of judicial combat. In northern Germany itself, however, trial by battle seems to have died out by the end of the thirteenth century, for there are no late medieval records of judicial duels. ${ }^{11}$

Subsequently, there are several examples of trials by combat with shields and swords from late medieval Swabia, which at the time comprised the upper watersheds of the Danube and Rhine Rivers, including Alsace and the Neckar River watershed. Although the Schwabenspiegel did not acquire its title until the seventeenth century, and was originally meant to describe German law in all imperial jurisdictions, its rules for duelling appear to have been particularly adapted to this region. In Augsburg, the chronicler Ehrhard Wahraus noted that in 1409 he had seen two men fight a duel "behind shields" with swords and knives or messers in lists that had been constructed in the wine market. One of the men stabbed the other to death. In 1432 two men in Konstanz fought a duel with swords and tall shields. In Hans Talhoffer's manuscript from 1467, produced for Count Eberhardt of Württemberg, he begins the sequence depicting a duel with tall shields and

10 Liber Papiensis: Leges Langobardorum, ed. Bluhme \& Bonensi, p. 499, \65; p. 524, \3. Milan: Antiquitates Italicae medii aevi, ed. Muratori, vol. 3, col. 637. The dating of this last text comes from Hyde, Padua in the Age of Dante, p. 6. Frederick II: “...campiones habeant clavas equales, non spinosas, nec cum aguzonibus...” Historia diplomatica Friderici Secundi, ed. Bréholles \& De Albertis de Luynes, vol. 4, part 1, 108-9. Military tribunals: Keen, The Laws of War in the Late Middle Ages, 19; Cavina, Il sangue dell'onore: Storia del duello, 47-9.

11 “...en blot svert in der hant, unde en umme gegort oder tvei, dat stat an irme kore." Des Sachsenspiegels erster Theil, ed. Homeyer, book 1, tit. 63.4, p. 219. Der Schwabenspiegel oder schwäbisches Land- und LehenRechtsbuch, ed. Lassberg, c. 79, §II.B, p. 38. Deutschenspiegel und Augsburger Sachsenspiegel, ed. Eckhardt \& Hübner, 2nd ed., c. 88, $\int \S 7-8$, p. 175. An exception to the disappearance of the judicial duel in Saxony seems to be the city law of Zwickau (on the Elbe watershed) from 1348. This may have to do with the town's proximity to Bohemia and Bohemian law. See the Zwickauer Rechtsbuch, ed. Ullrich, p. $26 \mathrm{ff}$. 
swords with the words "Here I stand in the Swabian manner, as one does in [Schwäbisch] Hall." At the end of the Middle Ages, this last town gained a reputation for being one of the few jurisdictions in Europe which still allowed judicial duels, making it a magnet for bravos and a centre for early duels of honour. ${ }^{12}$ Though records are few and centuries between, it seems that, unlike other parts of the Carolingian dominion, the former territory of the Alemannic law continued to consider swords the customary weapons of judicial combat throughout the High Middle Ages.

Not all German-speaking regions let duellists fight trials by battle with swords, however. Between the lands where Saxon legal customs dominated and the lands ruled by Swabian laws lay Franconia, a region with its own set of customs. Medieval Franconia had different borders from its modern counterpart. It occupied the watersheds of the Main River and the Middle Rhine from roughly Worms to Bonn, including lands that had once belonged to the Ripuarian Franks. Many towns in this region began recording their oral legal traditions in writing in the thirteenth and fourteenth centuries, in documents known as Weistimer. Where these laws specify judicial duelling weapons, they always speak of clubs (Kolben or Kolffen). Such references can be found in the Weistümer of Alzey, from 1300; Bacharach, from after 1350; Gelnhausen, from 1360; and the general Kampfgericht of Franconia, recorded in the first half of the fifteenth century. ${ }^{13}$ Some of the most detailed duelling ordinances came from Franconian towns like Würzburg and Nuremberg, which lay at the edges of the Rhine watershed. These towns had frequent commerce with Swabian lands because they were the portage points to the Danube river system, and consequently they most likely needed their detailed legal texts to make clear the differences between their legal customs and those of neighbouring Swabian lands. ${ }^{14}$ In these Franconian towns, litigants all fought with clubs according to Franconian practice. At the beginning of Talhoffer's illustrations depicting men with clubs and tall shields in the Württemberg codex, he writes, "Here I stand according to Franconian law." The Fecbtbuch of Peter Falkner from 1495 also begins its section on fighting with maces and

12 Ehrhard Wahraus: Chroniken der schwäbischen Städte: Augsburg, vol. 1, p. 231. Konstanz: Chronicle of Christoph Schulthaiß, in Constantini M. Triarchus Triumphalis, etc., ed. Speth, 297-9 (I am grateful to Jens Kleinau for drawing my attention to this case). Cod. icon. 394a, op. cit., f. 65v. For the duelling ordinance of Schwäbisch Hall, recorded in 1537, see Württembergische Jabrbucher: 1843, vol. 2, ed. Memminger, $142 \mathrm{ff}$.

13 Weisthümer, ed. Jacob Grimm, 7 vols. (Göttingen: Dietrich, 1840-1878), Alzey: vol. I, p. 799; Bacharach: II.213; Ordnung des Kampfgerichts von Franken: III.601-5. Gelnhausen: Hessisches Urkundenbuch ... vol 3: 1350-1375, p. 374. I am grateful to Jens Kleinau again for drawing my attention to the last ordinance.

14 The ordinance from Schwäbisch Hall comes similarly from the Swabian end of a portage. I am grateful to Anishinaabe tradition and more specifically to Dr. Niigaan Sinclair's discussion of the Selkirk Treaty Map and Cha Chay Pay Way Ti's Map at the following lecture for impressing on me the importance of watersheds and portages in cultural relations: "Appropriation or Appreciation," OCAD University, 28 November 2018. 
shields with the words "Note that this is the Franconian combat." 15 The reforms to Frankish law enacted by Charlemagne more than six centuries previous were still visible in regional custom in Talhoffer's time.

It is hard to determine the origins of the particular type of club found in Talhoffer's manuscripts. While illustrations of duelling clubs from other regions are not uncommon, they do not bear much resemblance to it. Talhoffer's club has a heavy head like a mace and is four-sided in cross section. The only Franconian legal text to elaborate on the shape or dimensions of the clubs it prescribes is an ordinance from Würzburg, which is contemporary with Talhoffer. That document calls for the weapon to have three corners and a spike at the top, not unlike the illustrations in the master's treatises. Outside the corpus of Fechtbücher, the only analogous contemporary example known to this writer is the wooden club depicted in the tournament book of King René of Anjou, from 1460. It too has been planed down to faceted surfaces, but it is eight-sided in cross section and more regular in thickness. Unlike Talhoffer's clubs, it has also had its point cut off, and possesses a round guard. ${ }^{16}$

One may also note a less obvious resemblance between Talhoffer's clubs and the 'prismatic' iron and bronze mace heads found in medieval Transylvania and Hungary. These roughly contemporary devices were cylindrical in shape, growing thicker towards their tip, and octagonal in cross section, having eight flat faces without flanges. Their origins trace back to steppe cultures farther east, and they were also widely adopted by the Seljuk Turks in the Near East. While Hungary and Anatolia may seem distant from Franconia, it must be remembered that they were only one portage away on a busy riverine trade route. The content of the treatise Bellifortis, which shares space with Talhoffer's work in one of his personal manuscripts, arrived in German lands by the same path on a similar timeline. Its author, Konrad Kyeser, was a physician who joined the disastrous crusade led by King Sigismund of Hungary against the Turks. After the defeat at Nicopolis in 1396 Kyeser's enmity with Sigismund led him to live in the mountains of Bohemia, where he fortuitously found illustrators to record the marvels of military technology he had seen abroad. An avenue for further research into the origin and spread of faceted clubs may be to investigate art and sculpture from Franconia specifically, but also the entire Danube trade route, in search of more analogues to these weapons. ${ }^{17}$

What can be said about the swords and clubs found in Talhoffer's duelling sequences is that we cannot assume that they were representative of judicial duels across Europe

15 Würzburg: “Ordnung des bitzing, ca. 1447," in Knapp, vol. I, part 2, p. 1281; Nuremberg: "Ordnung des Kampff-Gerichts des Burggraffgthumbs zu Nürnberg," in Teutsches Corpus Iuris, ed. Stephan, vol. 1, p. 709. Cod. icon. 394a, op. cit., f. 53v. "Merck daß ist der Frenckisch kampf..." in Peter Falkner, Kunste zu Ritterlicher Were, Vienna, Kunsthistorisches Museum, MS KK5012.

16 “...ieder kolb soll haben drei ecken u. fornen ein spitzen." "Ordnung des bitzing," in Knapp, vol. I.2, p. 1281. René d'Anjou, Traité de la forme et devis comme on peut faire les tournois, Paris, Bibliothèque nationale de France, MS fr. 2695, f. 31v.

17 Fărcaș, op. cit.; Z. Boldog, "A prismatic mace-head from Dunaföldvár," 183. Kyeser: KB MS Thott, 290.2, 12r-48v; White, "Kyeser's 'Bellifortis"' 437. 
throughout the Middle Ages. Talhoffer depicted the weapons that could theoretically be used in his own period, in the regions with which he was familiar. Even within the fairly limited time and place that he operated, legal practices differed from one jurisdiction to the next, and the rules for trial by battle, though conservative, could absorb new developments.

\section{I.3. Shields}

The shields for judicial duels described and depicted in medieval European sources show a great variety of forms, but most do not resemble the tall and unusually shaped specimens found in Talhoffer's manuscripts. Textual records are less helpful on this subject, as most of them simply prescribed that judicial duellists should use "a shield" (scutum, escu, or schild), without providing further detail. This ambiguity suggests that duelling shields were usually no different from other kinds of shields and needed no special description. Manuscript illustrations are more useful in providing specific information about their form. From the thirteenth century onwards, French manuscripts usually depicted judicial combatants carrying triangular shields of the "heater" type, which were also common in military contexts. ${ }^{18}$ In the Anglo-Norman tradition, duellists' shields were rectangular, ranging in size from early examples that covered fighters from shoulder to knee, to later targes that were only slightly larger than bucklers. ${ }^{19}$ These designs are unlikely to have been the direct ancestors of the south German type.

Notably, the shields described in thirteenth- and fourteenth-century German legal treatises also do not resemble the Talhoffer type. The Sachsenspiegel says quite clearly that a judicial duellist should have "a round shield in the off hand made of nothing but leather and wood, though the boss can be iron." The artist for the fourteenth-century copy of the manuscript now held in Wolfenbüttel interpreted this instruction as a large centreheld shield that would be slightly less than a metre in diameter in real life. Another copy, from Dresden, illustrates the duellists holding shields a little larger than bucklers. The instruction to use round shields also carried over into the Schwabenspiegel and the Deutschenspiegel, where it spread in many manuscript copies. ${ }^{20}$

18 An exception is a marginal grotesque holding a horned club and a round red and white targe in the margin of a manuscript of the Decretals of Gregory IX from southern France, circa 1280. Tours, Bibliothèque municipale, MS 0568, f. 308. The image may be seen at http://initiale.irht.cnrs.fr/decor/9378, accessed 1 January 2019.

19 An example of the large type can be found in a clerk's doodle on a Curia Regis roll from 1249, reproduced as the frontispiece of Select Pleas of the Crown, ed. Maitland. The smaller type is depicted in stained glass at York Minster and reproduced in French, York Minster: The Saint William Window, plate 10. See also Russell, "Accoutrements," 436-7.

20 Sachsenspiegel: "Enen senewolden schilt in der anderen hant, dar nicht denne holt unde leder an ne si, ane die bokelen, die mut wol isern sin." ed. Homeyer, p. 219. Wolfenbüttel, Herzog August Bibliothek, Cod. Guelph. 3.1 Aug. 2, f. 26r; Sächsischen Landes- Staats- und Universitätsbibliothek Dresden, Mscr. Dresd. M.32, f. 20r. Schwabenspiegel, ed. Lassberg, op. cit. p. 38; Deutschenspiegel, op. cit., pp. 175-6. 
Meanwhile, most of the Franconian Weistümer that discuss trial by battle simply call for duellists to use "ein schild," which likely meant they assumed this piece of equipment was no different in design from a common military shield. The duelling ordinance of Nuremberg from 1410 instructs that the shield should be made from nothing but wood, lime and sinew, and covered with a white linen cloth marked with a red cross. It does not, however, say anything about the shield's size or shape. Nevertheless, the custom of Bacharach, written before 1350, calls for duellists to be prepared "myt syme roiden schilde," another reference to a round shield. ${ }^{21}$ Consequently, not only are there no examples of tall shields before the fifteenth century, there is even evidence that duellists in German lands were using shields of an entirely different shape.

When did the "longshield" (as the website Wiktenauer dubs it) first appear and where did it come from? An intriguing clue comes from Bohemia. A bilingual Latin-Czech manuscript of Bohemian law, the Ordo judicii terrae, or Řád práva zemskébo, contains glosses written sometime after the death of Emperor Charles IV in 1378. One gloss, on a passage about a judicial duel between a burgher and a peasant, says "According to the law of old, they used to duel with clubs and small shields carried by weapons-bearers, but now they may fight with swords and great shields." 22 This passage would place the appearance of the longshield in Bohemia in the third quarter of the fourteenth century or later.

The Bohemian law accords with scattered scraps of evidence from south German lands. The first unambiguous evidence for tall shields I can find is the account of the duel between Hans Roth and Hans Riem at Konstanz in 1432 over an accusation of malicious sorcery. There, both men had a shield that reached their head (Kopff reichende Schild). At roughly the same time (circa 1430) an anonymous treatise on arts and wonders included an image of two men fighting with spiked clubs and rectangular shields sporting coneshaped central bosses and sets of three spikes protruding from their upper and lower rims. The only German legal document to mention a shield of the Talhoffer type is the Ordnung des Bitzing of 1447 from Würzburg. That ordinance calls for the use of "a shield that has three spikes on each side and is as long as the man [who carries it]." (One version of the Nuremberg duelling ordinance also allows for spikes on the top and bottom of the shield. $)^{23}$ It is therefore likely that in the first half of the fifteenth century, tall shields were a relative novelty that had appeared in south German lands within living memory, perhaps even within Talhoffer's own lifetime.

21 “Ordnung des Kampff-Gerichts des Burggraffgthumbs zu Nürnberg," op. cit., \ 11, p. 709. Bacharach: Weisthümer, ed. Grimm, II.213.

22 "Řád práva zemského - Ordo iudicii terrae," in Codex juris Bohemici, ed. Jireek, vol. 2, part 2, p. 198. "Et juxta antiqua jura cum baculis et clypeis parvis, quos hastiferi deferent, duellabant; nunc autem, duellare debent cum gladiis et magnis clypeis..." Ibid., p. 219, \ 29.

${ }^{23}$ Constance: Chronicle of Christoph Schulthaiß, ed. Speth, op. cit., p. 298. There was also the duel "behind shields" mentioned by Wahraus, op. cit., 231. Spiked shields: Vatican, Biblioteca Apostolica MS Pal. Lat 1888, f. 89v. Würzburg: "Item: ein schilt, der uf ieder seiten hat drei spitzen u. als lang der man ist." Ordnung des bitzing, in Knapp, p. 1281 Nuremberg: in Teutsches Corpus Iuris, ed. Stephan, vol. 1, p. $714, \int 50$. 
There is, however, a much older precedent for the Talhoffer shield. Nearly two centuries before the duel at Konstanz, tall shields and shields with spikes made an appearance in the Livre des assises de la cour de Barons, which was part of the collection of legal treatises known as the Assizes of Jerusalem. John of Ibelin, Count of Jaffa, wrote this treatise between 1264 and 1266 to record the customs of the high court of the crusader kingdom of Jerusalem as they had existed before Saladin reconquered that city in 1187. In the section about cases of homicide where both the accuser and the accused are knights, this treatise calls for a judicial duel on foot in which each man is equipped with "a shield which one calls a harace, which is larger than him by half a foot or a full palm, and has two piercings together, in such a place that one can see one's adversary through these holes..." In other kinds of judicial battles between knights, "the shield should have two spikes, one in the middle of the shield and one below on the foot, and they should be of any size and length [the knight] wants, up to a foot long but not more, and the shield can have as many sharp iron spikes or blades as he wants." 24 In 1369, this treatise was also adopted as the official reference book for the high court of Cyprus, although no judicial duels seem to have been held there after that date.

Shields like these are not found in any other European legal treatises of the thirteenth or fourteenth centuries, until the brief reference in the gloss of the Bohemian Ordo iudicii terrae. They seem to have developed in the Middle East. Arabic military treatises of the time do not contain direct analogues, but they do mention some shields from which the harace may have derived. The late twelfth-century Tabșira, written for Saladin by the engineer Murdua bin Alī al-Tarsūsī, describes two kinds of shields used by the Franks. The tariqa was a long shield that was round on top but gradually narrowed to a point, probably representing the "kite" shield popular in Europe at the time. The januwiya, on the other hand, was similar to the tariqa, but flat on the bottom, so that foot soldiers could rest it on the ground and create a shield wall resistant to archers. It seems to have been an early form of pavise, and indeed the word most likely derives from Genoa, since it does not have a clear etymological root in Arabic. ${ }^{25}$ Scaled slightly larger and pierced with holes, this latter shield may have become the barace.

Despite the time and geographical distance separating the Assises de Jerusalem from the German fight book corpus, there are notable similarities between these books. One manuscript of the Assises from the first half of the fourteenth century has a line drawing in the margin of a knight carrying a spiked shield as described in the text. It is depicted as a heater type with a spike protruding from its lower rim, and concentric circles representing the second spike at its centre boss. This shield appears to be decorated with three clusters of five dots in the shape of flowers. A long shield with many spikes depicted

24 "...une targe, que l'on apele harace, qui soit plus grant de lui demi pié ou plaine paume, et laquel ait .ii. pertuis de comunal grant en tel endroit qu'il puisse veir son aversaire par ceaus pertuis." John of Ibelin, Le Livre des Assizes, ed. Edbury, tit. 89, p. 236. "...et en l'escu doit avoir .ï. broches, l'une en mi l'escu et l'autre au pié desout, et doivent estre de tel groisse con il vodront et de tel longor jusques a .i. pié mais neent plus." Ibid., tit. 90, p. 240.

25 Claude Cahen, “Un Traité d'armurerie composé pour Saladin,” 137; 156, n. 3. 
in the earliest of the Talhoffer manuscripts, dating from circa 1448, is also decorated with a similar motif: four clusters of five or six dots are arranged around central dots in flowerlike patterns. Another German treatise, the so-called Cluny Fechtbuch created in the last quarter of the fifteenth century, shows two figures fighting with tall shields bored through with a matrix of piercings, not unlike the ones on the barace described in the Assises. ${ }^{26}$ Many more duelling shields in the corpus of German Fechtbücher have spikes or blades protruding from their rims. Although none of the five surviving manuscripts of the Assises de Jerusalem are known to have sojourned in German lands during the Middle Ages, it may be that a copy of the text—or perhaps the oral tradition that it represented-found its way to the Rhine-Danube network towards the beginning of the fifteenth century.

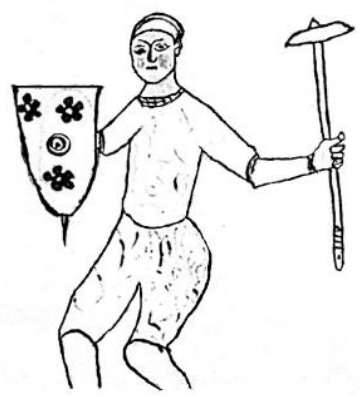

Fig. 1 Duellist carrying a spiked shield and horned club, from a manuscript of the Assises de Jerusalem. After Oxford, Bodleian Library, MS Selden Supra 69, f. 104 r (detail).

The transmission of specialized duelling shields from the Mediterranean world to Bohemian and south German lands mirrors the better-documented history of pavises generally. In Italy, the long kite shield was not supplanted by the triangular heater shape in the thirteenth century as occurred farther north. A larger, more rectangular version of the kite shield, behind which archers could shelter, was first mentioned in the thirteenth century, and popularized by companies of Italian mercenary archers who brought it to France during the Hundred Years' War. German writers of the time also knew of a large rectangular shield that rested on the ground, calling it a Setzschild or Setztartsche. The Hussite wars of 1419 to approximately 1434 sparked the development of a distinctively Bohemian form of the pavise with a vertical rib down the length of its centre line, and occasionally a wooden hook or beak in the centre of its top edge. ${ }^{27}$ The tall German duelling shield, with a vertical rib-like boss and often hooks at its head and foot, was likely

\footnotetext{
26 Shield pictured in the Assises: Oxford, Bodleian Library, MS Selden Supra 69, f. 104r. Shield in Talhoffer: Gotha MS Chart. A.558, f. 24v. Cluny Fechtbuch: Paris, Musée national du Moyen Âge, MS Cl. 23842, f. 180r.

${ }^{27}$ Denkstein, "Pavises of the Bohemian Type, II," 167-9, 172-9, 184-5. DeVries, "The Introduction and Use of the Pavise in the Hundred Years War," 98.
} 
an offshoot of the same influences, as soldiers and materiel moved through the upper Danube on their way to and from the wars.

Outside of south German lands and the Assises de Jerusalem, specialized duelling shields occurred only as isolated outliers. In the Archives Nationales de France, a seal dated broadly to the fourteenth century depicts a duellist's club with horns superimposed over a heater-type shield bearing a spike in the centre of its rounded lower rim. From behind the centre of the shield's upper edge, a shaft and spearhead protrude. Two other lines emanating from the shield's upper edge may represent either decorative curlicues or hooks that were part of the shield. The legend around the rim reads "Seal of Henri Chaillau, the fencer of Châlons." 28 Although horned clubs are found in some sources from the French-speaking realm, this appears to be the only French reference to a spiked duelling shield.

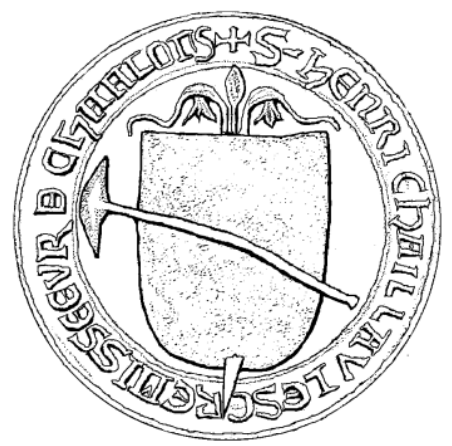

F.g. 2 Seal of Henri Chaillau, featuring a spiked shield and horned club. Fourteenth century. After Paris, Archives nationales, Collection de sceaux, no. 5860.

In another case, a marginal drawing in a Book of the Apocalypse shows apes facing off with clubs and what may be early Talhoffer-type shields. The shields are kite-shaped and as tall as their wielders, an unusual form to find in a French manuscript dated to 1313. Each shield has a large notch in its rim, resembling a lance rest but positioned on the wielder's lower left side rather than the upper right corner. ${ }^{29}$ The manuscript was created for Isabella of France, Queen of England, most likely to commemorate her visit to Paris that year along with her husband, Edward II, on which occasion her father reaffirmed his commitment to go on a crusade. ${ }^{30}$ To my knowledge, no other illustration of French or English shields depicts them as having that notched shape.

28 “S. HENRI CHAILLAV L'ESCREMISSEEVR DE CHAALONS," Douet d'Arcq, Collection de sceaux, part 1, vol. 2, p. 396, no. 5860. Douet d'Arcq thought the shield was a steaming cauldron and the club was a fire rake, but in light of the seal's legend, this interpretation is unlikely.

29 Paris, BnF, MS fr. 13096, f. 32r.

30 Paris, BnF, MS fr. 13096, f. 32r. Bergot, “L'Apocalypse d'Isabelle de France (1313)," 70. Suzanne Lewis, "The Apocalypse of Isabella of France: Paris, Bibl. Nat. MS Fr. 13096," 226-7. 


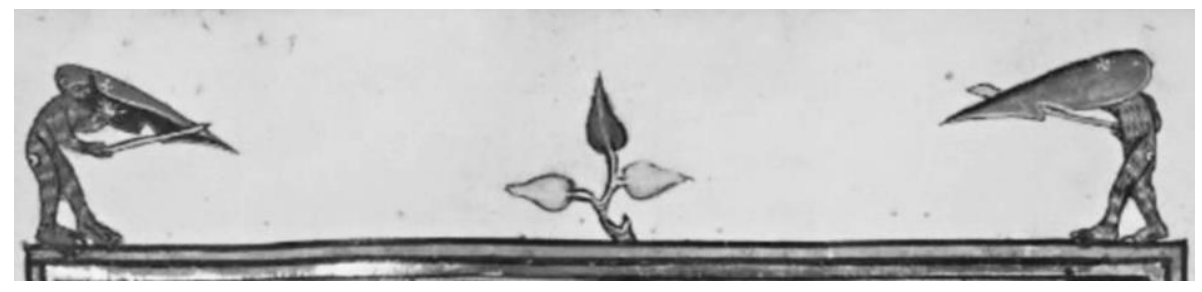

Fig. 3 Apes with notched kite shields, from the margins of a manuscript of the Book of the Apocalypse, 1313. Paris, Bibliothèque nationale de France, MS fr. 13096, f. 32r (detail).

As was the case for the prismatic club and the Near East, there are examples in one of Talhoffer's personal manuscripts of knowledge transmission from the Middle East and the greater Mediterranean world. In the pages following Talhoffer's own treatise, the Thott manuscript contains a treatise on the anatomy of internal organs by a writer who is referred to as the Jew Ebreesch (i.e. Hebraic), who cites a "Maister Allmonser" and his book "panthagin". As Diether Bachmann has noted, these are references to Manșūr ibn Ilyās (1380-1422), a Persian physician who wrote a treatise on anatomy, and the separate medical treatise known as the Liber Pantegni, written by Constantine the African, an eleventh-century Tunisian physician who migrated to Italy and became a monk at Monte Cassino. In addition, there follows an explanation of Hindu-Arabic numerals, a reckoning system that, while known to a few European mathematicians since Fibonacci, was only just becoming popularized in German lands. ${ }^{31}$ Clearly, Talhoffer was collecting specialized technical knowledge from well outside his local sphere.

Consequently, in south German lands, specialized duelling shields appear to have been a short-lived phenomenon that existed mainly in the first half of the fifteenth century. Rather than having an ancient or particularly Germanic origin, they followed flows of migration from the Middle East to their new home. After their appearance in the Würzburg ordinance of 1447, they were only ever mentioned in the Fechtbücher. However, among the German fighting masters their popularity continued for several generations more, perhaps as a late medieval form of re-enactment.

\section{I.4. Clothing}

In thirteenth-century legal treatises, clothing for judicial duelling was not much different in style from other contemporary apparel. The illustrations in the Wolfenbüttel and Dresden manuscripts of the Sachsenspiegel show duellists fighting in hose and loose kneelength tunics. The text says "They should put on as much leather and linen apparel as they want. Head and feet are bare in front, and on their hands they should have nothing but thin gloves. ... A jerkin without sleeves goes over the gear." These instructions were copied virtually word-for-word in the Schwabenspiegel and the Deutschenspiegel. A thirteenthcentury recension of the Sachsenspiegel originating in Augsburg substitutes wool for linen

31 KB MS Thott 290.2, ff. 141v, 149v, 150v; “Jud Ebreesch," Wiktenauer, note 6, https://wiktenauer.com/wiki/Jud_Ebreesch\#cite_note-6, accessed 1 January 2019; Arabic numerals: Hill, pp. 42-3, tables XXIII-XLIII, pp. 62-95. 
and adds that each of the combatants should have not only as much apparel as he wants, but also as much as his opponent wears, but those treatises keep the rest of the passage intact. 32

Furthermore, it was not clear from the treatises of this period that knights should fight judicial battles any differently than burghers or peasants, for there is no mention of armour. The only thirteenth-century German treatise to allow steel apparel was the city law of Colmar in Alsace, which permitted both combatants a hauberk (hassberch). ${ }^{33}$ Unlike France, where knights were permitted to fight judicial duels in full armour on horseback, thirteenth-century German customals reflected a society where knights were not necessarily much wealthier or more influential than burghers.

Rules for clothing appear to have been much the same as Saxony in Franconia. A Weistum from Bacharach dating from before 1350 says that a combatant should appear with "his jerkin taken in, ... with his white felt, with his hat bound on, with all those things that are proper for combat. ${ }^{34}$ The jerkin may be an example of the tightly fitted clothing found later in the fighting treatises, or it may simply have been hiked up and belted in. Fitted clothing was also making an appearance in images of duellists in France and England at this time. ${ }^{35}$ References to felt also turn up in French and English documents about trials by battle. It may have been used to provide some degree of padding. ${ }^{36}$

The slightly later duelling rules from Gelnhausen are the first to introduce two elements that would later appear in fight books from both Franconia and Swabia. The duellists' clothing was to be grey, and it was to have leather crosses attached in front and behind. This development appeared not long after the Black Death. Together with the rules about fighting barefoot, which had existed since the thirteenth century, these elements gave an air of penitence to the combatants, who were in some danger of causing the death of their opponent or meeting their Maker themselves. Grey clothing for duellists is also prescribed in the Franconian ordinance on duelling law from the first half of the fifteenth century. A Swabian account of a duel at Hall in 1405 describes the combatants as being dressed in ash-grey (leucophaeo vestitu), recalling the biblical expression "sackcloth and ashes". The Nuremberg duelling ordinance of circa 1410 also calls for crosses on clothing and shields, an echo of the ones worn by those who had vowed to go on crusade. In this context,

32 "Leder unde linen ding muten se an dun, alse vele alse se willet. Hovet unde vüte sint in vore blot, unde an den benden ne solen se nicht wen dunne hantzeken hebben; ... ene senewolden schilt in der anderen hant, dar nicht denne bolt unde leder an ne si, ane die bokelen, die mut wol isern sin, enen rik sunder ermelen boven der gare..." Sachsenspiegel, ed. Homeyer, book 1, tit. 63.4, p. 219. Schwabenspiegel, ed. Lassberg, \$79.II.B, p. 38; Deutschenspiegel und Augsburger Sachsenspiegel, Landrecht, c. 88, \8, p. 175.

33 “Das Recht der Stadt Colmar," in Deutsche Stadtrechte des Mittelalters, ed. Gaupp, vol. 1, \$ 39, p. 121. 34 “...syme einfaren rocke, ... mit syme wissen viltre, iyt syme uffgebunden buote, myt alle deme, daz. man zum kampfe begeert...” Grimm, Weisthümer, vol. 2, p. 213.

35 See, for instance, the late thirteenth-century French duellists in Berlin Staatsbibliothek MS Hamilton 193, f. 194r, or the early fourteenth-century English ones in the Smithfield Decretals, London, BL, MS Royal 10 E IV, f. 96v.

36 Russell, “Accoutrements," 437-8. Elema, 252-3.

16 Acta Periodica Duellatorum 7(1), 2019, Scholarly section 
some of the odder clothing choices in the fighting treatises, such as the combatants with "balaclava" headgear in Falkner and the Cluny Fechtbuch, make more sense. Very similar hoods appear in a French miniature from the early fifteenth century depicting a procession of flagellants. ${ }^{37}$ They represent the shame and penitence of their wearers.

Of course, most German Fechtbücher also included a section on duels in armour. These duels arose out of a slightly different legal tradition. Even as each geographical jurisdiction had customary laws that were beginning to be codified, Western Christiandom as a whole was starting to develop a body of law about how war was to be conducted and how fighting men were to resolve disputes among themselves. Military commanders had traditionally possessed some powers to arbitrate disputes among their troops. With the increasing use of foreign mercenary companies in the fourteenth century, international consensus began to develop the ius armorum, or customary law of arms. It came to be agreed that, after an army had disbanded, cases under this law could be heard in any court of a sovereign prince, regardless of the court's location or relation to the original crime. The law or arms regarded judicial duels more favourably than other customs did, and also permitted litigants to fight their battles in armour and on horseback, since all participants were already men at arms, and often aristocrats, who possessed such equipment already. ${ }^{38}$

Medieval chroniclers tended to discuss these armoured duels alongside other single combats of a less judicial nature. The Hundred Years War in France saw the rise of the deed of arms, a formal, arbitrated and regulated combat that blurred the distinctions between tournaments, warfare, and judicial duels. This phenomenon also appeared in the Holy Roman Empire as early as 1336, when Emperor Ludwig IV arbitrated a duel between his chamberlain Hector von Trautmannsdorf and the knight Seyfried der Frauenberger over the question of whether the latter "slanders his [Hector's] honour behind his back and claims himself to be better and to come of a better and nobler lineage than him." The Kaiser originally tried to settle the dispute by having both men produce documentation of their lineage, but when Hector was not satisfied with Seyfried's document, the Kaiser agreed to grant them a day to fight. The men pledged their shields and helms, implying that the duel was to be held in armour, and agreed to surrender their arms to their opponent if they were defeated, a practice up to then associated with tournaments rather than judicial combat. ${ }^{39}$

In 1386 the French prior Honorat Bovet produced the Arbre des batailles, a book which included a codification of the rules for armoured duels. Christine de Pizan expanded on his work in 1413, making special mention of the German empire. The nineteenth-century

${ }^{37}$ Gelnhausen: Hessisches Urkundenbuch, op. cit., 374. Franconia: Ordnung des Kampfgerichts von Franken, op. cit., p. 601. Duel at Hall: Crusius, Annales Suevici, book 3, p. 330. Nuremberg: "Ordnung des Kampff-gerichts,” op. cit., \11, p. 708-9. Falkner, 65v-67r. Cluny Fechtbuch: MS Cl. 23842, f. 181r. Flagellants: Belles heures de Jean, Duc de Berry, New York, Metropolitan Museum of Art, Cloisters Collection MS 54.1.1, f. $74 \mathrm{v}$.

38 Keen, Laws of War, 19-20, 41. Elema, 76-81.

39 On deeds of arms in general: Muhlberger, Deeds of Arms, 6-8. On Trautmannsdorf v. Frauenberger: Müller, Reichs Tags Theatrum, pp. 103-4. 
scholar Alwin Schultz collected ten cases of late medieval German duels dating between 1347 and 1478, though at least one of them was fought in grey clothing without armour. These late medieval duels and the references to armour in them would benefit from a more in-depth study and a comparison to the fight books, although it is beyond the scope of this article. ${ }^{40}$

Thus, duellists' clothing or armour was a marker for two separate but related legal traditions. Those who fought judicial combats barefoot and without armour were following an older set of customary procedures rooted in local land law, while those who fought in armour were following a younger, military-based custom that had developed in a wider West European context. These two sets of customary laws coexisted and sometimes even overlapped in their jurisdictions, a contradiction that bothered medieval jurists far less than their modern counterparts.

\section{I.5. Duels between a man and a woman}

One more unusual kind of judicial duel also occurs in the manuscripts of Talhoffer and his successors: the duel between a man and a woman. In this scenario, the man fights with a club while standing in a waist-deep pit, while the woman moves freely around him, armed with a stone tied in a length of cloth. The duel occurs as a sequence of illustrations in Talhoffer and Paulus Kal, while the anonymous book of arts and wonders, Hutter and the Cluny Fechtbuch include it as a single image. ${ }^{41}$

The website Wiktenauer refers facetiously to duels of this kind as "Marriage Counseling," but when they are described in medieval legal treatises, they are always cases of rape. The medieval term for this crime was Notnumpht, a word which could also encompass kidnapping and associated assault. The earliest legal treatises that prescribe judicial duelling as a remedy for it were written in a relatively confined region around Munich. The city law of Augsburg from 1276 says that if there were no witnesses who saw or heard the rape, the woman could bring an accusation against the rapist in court, but he could clear himself by swearing single-handed, that is, by swearing a simple oath to his innocence without having any associates to join him as oath-helpers. If, however, the woman was unwilling to accept his oath, then she was obliged to fight him in person. The man was to stand in a hole up to his navel, armed with an oaken cudgel, while the woman was armed with a small garment (roeclin) in which there was a fist-sized stone. Whichever of the two was defeated was to be buried alive. ${ }^{42}$

Ruprecht von Freising's Freisinger Rechtsbuch of 1328 calls for much the same scenario, except it specifies that the man's left hand should be bound behind his back and the woman's stone should weigh one pound. In this case, the man who lost was to be beheaded, while a woman who lost was to have her hand chopped off. The Rechtsbuch of

\footnotetext{
40 Bovet, ed. Nys, 222-46. Christine de Pizan, ed. Willard, 199-200. Schultz, Deutsches Leben, 369-70. 41 Talhoffer MS Thott 290.2, ff 80r-84r. Kal, MS Cgm 1507, ff. 49v-51v. Arts and Wonders: MS Pal. lat. 1888, f. 94r. Cluny Fechtbuch, MS Cl. 23842, f. 194v. Hutter, MS Cg. 3711, f. 58a.r.
}

42 Stadtbuch von Augsburg, ed. Meyer, art. 31, \1, pp. 89-90.

18 Acta Periodica Duellatorum 7(1), 2019, Scholarly section 
Kaiser Ludwig IV the Bavarian from 1346 also mentions a duel between a woman and a man in cases of rape, but it provides no details about how the combat is to be carried out. ${ }^{43}$ The conditions laid out in these texts seem to have been designed to discourage accusations of rape from being brought before the courts. Needless to say, there does not seem to have been any case law from Bavaria in which a duel of this sort was ever carried out in real life.

There was, however, one duel between a man and a woman held some distance away, in Bern, in 1288. The laconic chroniclers of the time gave the incident no more than one sentence each. The late thirteenth-century annals of Colmar reported for that year "In the city of Bern, a woman is known to have defeated a man in a duel." The Chronica de Berno from circa 1325 said "In the year of the Lord 1288 there was a duel in Bern between a man and a woman on the octave of the Innocents, but the woman prevailed." Conrad Justinger's Berner Chronik had little more to add in 1420: "Men say that in 1288, on the octave of the Innocents, a battle occurred in the marketplace where the churchyard wall now stands; a man and a woman fought each other and the woman won." From these sources, the story was copied into Diebold Schilling's Spiezer Chronik and the sixteenthcentury chronicle of Johann Stumpf. This is the sole example in European history of a trial by battle between a man and a woman that the litigants pursued all the way to combat and fought in person. However, none of the chronicles provides the combatants' names or describes the nature of the suit or the weapons in any way. ${ }^{44}$

The duel in Bern may have spread the fame of the procedure. Around 1300, the poet Heinrich von Neustadt from Vienna included an episode of a woman duelling a man in his epic poem Apollonius von Tyrland. This poem was one of several versions of the Apollonius story circulating Europe at the time, but none of the others contained this incident. In Heinrich's version, the woman challenges the man because he has slandered and attempted to violate her sister. Her weapon is a stone weighing three pounds sewn into a cloth two ells long. The man, as per the Bavarian tradition, stands waist-deep in a narrow pit with one hand tied behind his back. ${ }^{45}$

By Talhoffer's time, the procedure seems to have become a theoretical possibility in some Franconian courts. An ordinance from Würzburg dating to circa 1447 says that in a duel where a woman accused a man, the woman should have three maces, each one made from a shaft of hazel one ell long, with a one pound head of stone attached to it with leather thongs. As in other cases, the man was to stand in a hole. He was armed with three clubs, each one an ell long and two man's thumbs thick. Every time he struck at the woman and

\footnotetext{
43 Ruprecht von Freising, ed. Claußen, \ 137. Rechtsbuch Kaiser Ludwigs, ed. Volkert, art. 58, p. 291.

44 The text of the entries in the Annales Colmarienses, Chronica de Berno and Berner Chronik is recorded in Neumann, Der gerichtliche Zweikampf, p. 206, n. 1118. Schilling, Spiezer Chronik, p. 112. Johannes Stumpf, Gemeiner loblicher Eydgnoschafft, book 8, cap. 6, f. 250v. A surviving Bernese legal customal from seventy years before the incident does not mention duels between a man and a woman, but does say that trial by battle can be used in cases of secretive murder and violent nocturnal home invasion. Zeerleder, Urkunden, vol. 1, p. 185.
}

${ }^{45}$ R.W. Pettengill, "The Source of an Episode in Heinrich von Neustadt's Apollonius," 45-6. 
his hand touched the ground, he was to lose a club. If he lost three clubs, he would lose the battle. Likewise, if the woman struck at the man and missed, she would lose a club, and if she lost the battle she could be buried alive. ${ }^{46}$ Although German chronicles were more plentiful and detailed in the fifteenth century than in the thirteenth, there are, unsurprisingly, no records of anyone holding such a battle in earnest.

Nevertheless, case records exist in which battles between a man and a woman were threatened. In 1405, Els, daughter of Otto Spara of Schwarzach, sent Albrecht Lotter of Wiernsreut a summons to answer for an unspecified offence. "If he confirms it then she will be satisfied, but if he denies it, she wishes to make it true with her stone on his head, according to the law of battle." The case was delayed three times, after which a further ten months went by before the clerk added "Judged in Fürth after [the feast of Saint] Vitus in the year 1406." Another case in 1435 ends with the words "it has been judged with law (mit recht verurteilt) on the Monday before Maundy Thursday." ${ }^{47}$ This last remark most likely means that the case was settled according to a process recorded in academic written law, rather than a customary law procedure like battle. A judicial duel in either case would surely have caused enough sensation to have been noted by one of the many chronicles that recorded happenings in the Nuremberg region.

These precedents raise important questions about the combats portrayed in the Fechtbücher. It is unlikely that either Hans Talhoffer or Paulus Kal ever witnessed a judicial duel between a man and a woman or talked to anyone who had seen one. How then did they learn the plays they illustrated? Did they, like the historical martial artists of today, reconstruct the fight from scraps of historical knowledge and the application of physical principles? How did they go about this work? Furthermore, if today's martial artists attempt to re-create the plays of Talhoffer and Kal, are they in fact reconstructing a reenactment?

\section{I.6. Conclusion}

Until now, most historians have attempted to study German judicial duels from a national perspective. This focus is at once too broad and too narrow. German trials by battle were rooted in regional customary law that predated the Holy Roman Empire. Even in the fifteenth century, the autumn of this procedure's history, regional custom determined how it was carried out, particularly the rules for the weapons and equipment that were permitted. A fight master needed to know the differences in procedure between one city and the next.

At the same time, these legal customs could change and evolve, albeit slowly. Regions like Swabia, Franconia and Bavaria were positioned in an important trade nexus at the headwaters of the Rhine and Danube rivers, and not far from the Alpine passes. When south German jurists looked beyond their borders for legal precedents, they drew

46 “Ordnung des bitzing," in Knapp, vol. I.2, p. 1282.

47 “...iehe er ir das, das sey ir leib, langne er ir aber sein, so will sie es mit irem stein auf sein haubt war machen nach Kampfsrecht.” In Jung, Miscellaneorum, vol. 1 p. 187. Knapp, vol. 2, p. 418, n. 5. 
inspiration not only from German-speaking lands to the north, but also from the whole Danube watershed and even from the Mediterranean world. Without a world-historical perspective, it is easy to mistake such objects as the faceted club or the tall spiked shield for unusual local innovations, when in fact they were variations of weapons that had existed elsewhere for a long time.

Finally, it is important to question whether all the plays portrayed in the Fechtbücher were contemporary with their authors. At times, the masters themselves seem to have been reconstructing their scenarios from historical sources, and perhaps even re-enacting them. Only by examining the precedents on a longer timeline can we determine which parts of their work were tradition, innovation, or re-enactment.

\section{BIBLIOGRAPHY}

\section{II.1. Manuscript sources}

Eike von Repgow, Sachsenspiegel, Dresden, Sächsischen Landes- Staats- und Universitätsbibliothek, Mscr. Dresd. M.32.

------. Wolfenbüttel, Herzog August Bibliothek, Cod. Guelph. 3.1 Aug. 2.

Falkner, Peter, Kunste zu Ritterlicher Were, Vienna, Kunsthistorisches Museum, MS 5012.

Jean d'Ibelin, Assises de Jerusalem, Oxford, Bodleian Library MS Selden Supra 69.

Kal, Paulus, Fechtbuch, Munich, Bayerische Staatsbibliothek MS Cgm 1507.

New York, Pierpont Morgan Library MS M.457.

Paris, Bibliothèque nationale de France, MS fr. 13096.

https://gallica.bnf.fr/ark:/12148/btv1b10533304x, accessed on 1 January 2019

Paris, Musée national du Moyen Âge, MS Cluny 23842.

René d'Anjou, Traité de la forme et devis comme on peut faire les tournois, Paris, Bibliothèque nationale de France, MS français 2695, https://gallica.bnf.fr/ark:/12148/btv1b84522067.image, accessed on 1 January 2019.

Schilling, Diebold, Spiezer Chronik, Bern, Burgerbibliothek, Mss. h. h. I. 16.

https://www.e-codices.ch/en/list/one/bbb/Mss-hh-I0016, accessed on 1 January 2019.

Talhoffer, Hans, Fechtbuch, Berlin, Stiftung Preußischer Kulturbesitz, MS 78.A.15.

-----, Copenhagen, Kongelike Bibliotek, MS Thott 290.2.

------, Gotha, Universitäts- und Forschungsbibliothek, MS Chart.A.558.

------, Munich, Bayerische Staatsbibliothek, Codex iconographicus 394a.

Tours, Bibliothèque municipale, MS 0568.

Vatican, Biblioteca Apostolica Vaticana, MS Pal. lat. 1888.

https://doi.org/10.11588/diglit.9740\#0001, accessed on 1 January 2019. 


\section{II.2. Published primary sources}

Agobard of Lyons, Agobardi Lugdvnensis: Opera omnia, ed. L. Van Acker, Corpus Christianorum, Continuatio Medievalis LII (Turnhout: Brepols, 1981).

Antiquitates Italicae medii aevi, ed. Lodovico Antonio Muratori, 6 vols (Milan: Typographia Societatis Palatinae, 1738-1742).

Bovet, Honorat (aka Honoré Bonet), L'arbre de batailles de Honoré Bonet, ed. Ernest Nys (Brussels: C. Muquardt, 1883).

Capitularia Regum Francorum, ed. Alfred Boretius, Monumenta Germaniae Historica, Capitularia regum Francorum 1 (Hannover: Hahn, 1883).

Christine de Pizan, The Book of Deeds of Arms and Chivalry, ed. Charity Cannon Willard, trans. Sumner Willard (University Park, PA: Pennsylvania State University Press, 1999).

Chroniken der schwäbischen Städte: Augsburg, vol. 1 (Leipzig: S. Hirzel, 1875).

Crusius, Martin, Annales Suevici, 3 vols. (Frankfurt, Nikolaus Basse, 1595-6).

Deutschenspiegel und Augsburger Sachsenspiegel, ed. Karl August Eckhardt and Alfred Hübner, $2^{\text {nd }}$ ed. Monumenta Germaniae Historica, Fontes iuris 3 (Hannover: Hahn, 1933).

Deutsche Stadtrechte des Mittelalters mit rechtsgeschichtliche Erläuterungen, ed. Ernst Theodor Gaupp (Breslau: Josef Max \& Co., 1851).

Frederick II, Historia diplomatica Friderici Secundi, ed. Jean-Louis-Alphonse Bréholles \& H. de Albertis de Luynes, 6 vols. (Paris: Plon, 1817-1871).

Fuero general de Navarra, ed. Pablo Ilarregui and D. Segundo Lapuerta (Pamplona: Imprenta Provincial, 1869).

Hessisches Urkundenbuch: Urkundenbuch zur Geschichte des Herrn von Hanau und der ehemaligen Provinz.Hanau, ed. Heinrich Reimer, vol. 3: 1350-1375 (Leipzig: S. Hirzel, 1894).

Jung, Carl Ferdinand, ed. Miscellaneorum, vol. 1 (Frankfurt and Leipzig: n.p., 1739).

Knapp, Hermann, ed., Die Zenten des Hochstifts Würzburg: ein Beitrag zur Geschicbte des süddeutschen Gerichtswesens und Strafrechts, mit Unterstützung der Savignystiftung, 2 vols. (Berlin: J. Guttentag, 1907).

Leges Langobardorum, ed. F. Bluhme \& I.C. Bonensi, Monumenta Germaniae Historica, Leges 4 (Hannover: Hahn, 1868).

Lex Alamannorum, ed. Karl Lehman and Karl Augustus Eckhardt, 2nd ed., Monumenta Germaniae Historica, Leges nationum Germanicarum 5.1 (Hannover: Hahn, 1966).

Lex Ribvaria, ed. Franz Beyerle and Rudolf Buchner, Monumenta Germaniae Historica, Leges nationum Germicarum 3.2 (Hannover: Hahn, 1954).

Murḍa bin Alī al-Tarsūsī, "Tabșirat Arbāb al-Albāb," in Claude Cahen, "Un Traité d'armurerie composé pour Saladin,” Bulletin d'études orientales 12 (1947-8), 103-163.

Müller, Johann Joachim, ed. Des Heiligen Römischen Reichs Teutscher Nation Reichs Tags Theatrum, etc., 2 vols. (Jena: Johann David Werther, 1713). 
Ordonnances des roys de France de la troisième race, ed. Eusèbe Jacques de Laurière, vol. 1 (Paris: Imprimerie Royale, 1723).

"Řád práva zemskébo - Ordo judicii terrae," in Codex juris Bohemici, ed. Hermengild Jireek, volume 2, part 2 (Prague: I.L. Kober, 1867), 198-255.

Rechtsbuch Kaiser Ludwigs des Bayern von 1346, ed. Wilhelm Volkert, Bayerische Rechtsquellen 24 (Munich: C.H. Beck, 2010).

Ruprecht von Freising, Freisinger Rechtsbuch, ed. Hans-Kurt Clauen (Weimar: Böhlau, 1941).

Sachsenspiegels erster Theil oder das Sächsiche Landrecht nach der Berliner Handschrift v. J. 1361, des, ed. C.G. Homeyer (Berlin: Ferdinand Dümmler, 1861).

Schwabenspiegel, oder schwäbisches Land- und Lehen-Rechtsbuch, ed. F.L.A. von Lassberg, (Tübingen: Ludwig Friedrich Fues, 1840).

Select Pleas of the Crown, ed. F.W. Maitland, Selden Society 1 (London: Bernard Quaritch, 1888).

Stadtbuch von Augsburg, inbesondere das Stadtrecht von 1276, ed. Christian Meyer (Augsburg: Butsch, 1872).

Stumpf, Johannes, Gemeiner loblicher Eydgnoschafft Stetten, Landen, Völckeren Chronicke wirdinger Thaaten Beschreybung (Zurich: Christoffel Froschouer, 1548).

Teutsches Corpus Iuris, publici et privati, oder Corpus diplomaticus... ed. Joseph Stephan, vol. 1 (Ulm: Johann Conrad Bohler, 1717).

Weisthümer, ed. Jacob Grimm, 7 vols. (Göttingen: Dietrich, 1840-1878).

Wurzelmann, Mattheus, "Kampfgericht in Schwäbisch Hall," 1537, in Wurttembergische Jahrbücher: 1843, vol. 2, ed. Johann Daniel Georg Memminger (Stuttgart: J.G. Cotta, 1846).

Zeerleder, Karl, ed. Urkunden für die Geschicbte der Stadt Bern, 3 vols. (Bern: Stämpfli, 1853).

Zwickaner Rechtsbuch, ed. Günther Ullrich, (Weimar: H. Böhlau, 1941).

Zwierlein, Christian Jacob von, ed. Historisch-diplomatische Abhandlung von denen landesherrlichen Gerechtsamen des Hochfürstlichen Hauses Brandenburg über den Marktflecken Fürth, etc. (Anspach: Posch, 1771).

\section{II.3. Secondary sources}

Bartlett, Robert, Trial by Fire and Water: The Medieval Judicial Ordeal (Oxford: Clarendon Press, 1986).

Bergot, Louis-Patrick, "L'Apocalypse d'Isabelle de France (1313) et son lien avec un groupe de Bibles historiales," Questes : Revue pluridisciplinaire d'études médiévales 38 (2018): 63-79.

Boldog, Z., "A Prismatic Mace-Head from Dunaföldvár from the Time of the Mongol Invasion," Acta Archaeologica Academiae Scientiarum Hungaricae 63 (2012): 181-96. 
Canel, A. "Le Combat judiciaire en Normandie" Mémoires de la Société des antiquaires de Normandie 22 (1836): 575-655.

Cavina, Marco. Il sangue dell'onore: Storia del duello (Rome: Laterza, 2005).

Denkstein, Vladimír, "Pavises of the Bohemian Type, II: The Origin and Development of Pavises in pre-Hussite Europe," in Sborník Národníbo Mužea v Praze, Series AHistoria 18:3-4 (1964): 149-194.

DeVries, Kelly, "The Introduction and Use of the Pavise in the Hundred Years War," Arms and Armour 4:2 (2007): 93-100.

Douet d'Arcq, Louis-Claude, Inventaire de sceaux, part 1, vol. 2 (Paris: H. Plon, 1867).

Elema, Ariella, "Trial by Battle in France and England," (doctoral dissertation, University of Toronto, 2012).

Fărcaș, André-Octavian, "Maces in Medieval Transylvania between the Thirteenth and Sixteenth Centuries," (master's thesis, Central European University, 2016).

Fehr, Hans, Der Zweikampf (Berlin: Karl Curtius, 1908).

Fortner, Sandra, “'Kempflich angesprochen:' über Kampfgerichte und Kampfrecht,” in André Schulze, ed., Mittelalterliche Kampfesweisen: Der Kriegshammer, Schild und Kolben (Mainz: Philipp von Zabern, 2007), pp. 10-22.

French, Thomas. York Minster: The St. William Window, Corpus Vitrearum Medii Aevi Great Britain Summary Catalogue 5 (Oxford: Oxford University Press, 1999).

Grimm, Jacob, Deutsche Rechtsalterthümer, 2nd ed. (Göttingen: Dietrich, 1854).

Hill, G. P., The Development of Arabic Numerals in Europe (Oxford: Clarendon Press, 1915).

Lea, Henry Charles, Superstition and Force. Book 2. 1866. Reprinted as The Duel and the Oath (Philadelphia: University of Pennsylvania Press, 1974).

Keen, Maurice, The Laws of War in the Late Middle Ages (London: Routledge \& Keegan Paul, 2005).

Lewis, Suzanne, “The Apopcalypse of Isabella of France: Paris, Bibl. Nat. MS Fr. 13096," The Art Bulletin 72:2 (1990): 224-60.

Muhlberger, Steven, Deeds of Arms (Wheaton, IL: Freelance Academy Press, 2005).

Neumann, Sarah, Der gerichtliche Zweikampf: Gottesurteil, Wettstreit, Ehrensache, MittelalterForschungen, Band 31 (Ostfildern, Germany: Jan Thorbecke, 2010).

Nottarp, Herman, Gottesurteilstudien (Munich: Kosel, 1956).

Pettengill, R.W., "The Source of an Episode in Heinrich von Neustadt's Apollonius," The Journal of English and German Philology 13:1 (Jan., 1914): 45-50.

Russell, M.J., “Accoutrements of Battle,” Law Quarterly Review 99:3 (1983): 432-442.

Schultz, Alwin, Deutsches Leben im XIV und XV Jahrhundert (Vienna: Tempsky, 1892).

Sinclair, Niigan, “Appropriation or Appreciation," (lecture, OCAD University, 28

November, 2018). 
Talaga, Maciej, "A Kampfschwert from the $15^{\text {th }}$ Century-A Reinterpretation of the SoCalled 'Teutonic Estoc' from the Princes Czartoryski Collection in Cracow, Poland," Acta Periodica Duellatorum 3 (2015): 7-27.

Unger, Friedrich Wilhelm, Der gerichtliche Zweikampf bei den germanischen Völkern

(Göttingen: Vandenhoeck \& Ruprecht, 1847).

White, Lynne, Jr., "Kyeser's 'Bellifortis': The First Technological Treatise of the Fifteenth Century," Technology and Culture 10:3 (1969): 436-41.

White, Stephen D., "Proposing the Ordeal and Avoiding It," in Cultures of Power:

Lordship, Status and Progress in the Later Middle Ages, ed. Thomas Bisson (Philadelphia: University of Pennsylvania Press, 1995), 89-123.

Würdinger, Joseph, Beiträge zur Geschichte des Kampfrecbts in Bayern (Munich: C. Wolf \& Sohn, 1877). 